\title{
IMPLEMENTABLE POLICY CONSIDERATIONS IN THE ADVANCEMENT OF OFFICIAL INDIGENOUS AFRICAN LANGUAGES AS MEDIUMS OF INSTRUCTION AT INSTITUTIONS OF HIGHER EDUCATION
}

by Marko Svicevic*

\section{Introduction}

In late 2015, the \#FeesMustFall campaign swept across South Africa, leaving no public institution of higher education untouched. The campaign, a student-led protest movement which began in midOctober, initially stemmed from student frustrations relating to increases in university tuition fees. Beginning at the University of the Witwatersrand and moving to the University of Cape Town and Rhodes University, rapidly escalating to a nationwide student crusade, it later developed into a movement tackling issues of transformation, university language policies, tuition fee increases and university practices of outsourcing workers. At its peak, the \#FeesMustFall movement saw an estimated 15000 students march to South Africa's iconic Union Buildings, resulting in government announcing a zero percent fee increase for universities in 2016. ${ }^{1}$

This article attempts to analyse a single aspect of the \#FeesMustFall movement, namely, university language policies. The research problem is defined as an unjustifiable underdevelopment of indigenous African languages as mediums of instruction at institutions of higher education. The research problem is situated with defective university language policies. Firstly, most current language policies detract from a national framework on the advancement of indigenous African languages. ${ }^{2}$ Secondly, most current university language policies have no clear implementation plan and the advancement of their specified African indigenous language(s) remains unrealised.

* $\quad$ Fourth year BA (Law) LLB student, University of Pretoria.

1 B Bateman '\#FeesHaveFallen: Zuma scraps fee hikes for 2016' http://ewn.co.za/ 2015/10/23/FeesHaveFallen-Zuma-scraps-fee-hikes-for-2016 (accessed 21 August 2016).

2 For purposes of this article the term 'Indigenous African languages' refers to the nine official indigenous languages as mentioned in section 6(2) of the Constitution of the Republic of South Africa, 1996 (the Constitution) which are: isiXhosa, isiZulu, Sesotho, Sepedi (Sesotho sa Leboa), isiNdebele, Tshivenda, Xitsonga, Setswana and siSwati. This for the argument is directly related to the fact that official indigenous languages are afforded equal status, as opposed to other indigenous languages which do not share the same constitutional character. 
This underdevelopment of indigenous African languages can also be attributed to the 'Anglicisation' of the higher education sphere. ${ }^{3}$ Finally, this paper utilises and builds on the Language Policy for Higher Education ${ }^{4}$ and a 2005 Ministerial Committee Report ${ }^{5}$ on the development of indigenous African languages in universities, ultimately proposing implementable policy considerations in (re)addressing the underdevelopment of indigenous African languages as mediums of instruction across all public institutions of higher education. ${ }^{6}$

The focus of this article falls on the following premise: The Constitution of South Africa ${ }^{7}$ recognises and mandates the protection and development of all 11 official languages, which is also alluded to by numerous legislative texts and policy documents. ${ }^{8}$ The Anglicisation of South African universities has detracted from realising the provisions of section 6 of the 1996 Constitution, to the detriment of indigenous African languages.

The adoption of indigenous African languages as mediums of instruction at all public universities with a national framework on the advancement of such languages as envisaged in the Ministerial Committee Report on 'the development of indigenous African languages as mediums of instruction in higher education'. ${ }^{9}$

This article begins by outlining the basic constitutional and legislative principles which protect and enshrine all official South African languages. The argument that Anglicisation of universities detracts from the development of indigenous South African languages is then discussed with particular reference to the University of Cape Town and the University of the Free Sate. ${ }^{10}$ An analysis and comparison of current university language policies then assists in identifying shortfalls within university language policies. Specific attention is focused on the particular indigenous languages chosen by universities for advancement. Finally, several implementable policy

3 See para 3.1.1 and 3.1.2 below.

4 Ministry of Education 'Language Policy for Higher Education, November 2002' http://www.dhet.gov.za/HED\%20Policies/Language\%20Policy\%20for\%20Higher\%20 Education.pdf (accessed 13 October 2016).

5 'The Development of Indigenous African Languages as Mediums of Instruction in Higher Education Report' by the Ministerial Committee appointed by the Ministry of Education in September 2003 (the Ministerial Committee Report).

6 For purposes of this research paper, the term 'universities' and 'higher education institutions' are used synonymously in referring to the 26 public universities in operation in South Africa today.

7 The Constitution of the Republic of South Africa, 1996 (the Constitution).

8 See sec 27(2) of the Higher Education Act 101 of 1997; South Africa (1997) Ministry of Education, Education White Paper 3; Government Gazette 1196, July 24 para 2.77 - 2.81, South Africa (2002) Ministry of Education; Transformation and restructuring: A new institutional landscape for higher education; Government Gazette 855, June, 21, 30, 34 - 35, 48.

9 Ministerial Committee Report (n 5 above) para 48.8.

10 Ministerial Committee Report (n 5 above). 
considerations are proposed in addressing the current 'language crisis' universities are experiencing.

\section{Constitutional provisions enshrining languages and multilinguism}

Section 6 of chapter one, the founding provisions of the 1996 Constitution, recognises 11 official languages in South Africa. ${ }^{11}$ These are Sepedi (Sesotho sa Leboa), Sesotho, Setswana, siSwati, Tshivenda, Xitsonga, Afrikaans, English, isiNdebele, isiXhosa and isizulu. Although the Constitution of 1996 and the interim Constitution of $1993^{12}$ differ somewhat in their provisions, they do not materially deviate, in particular, on the explicit referral to the equitable use of all official languages.

The interim Constitution phrases the equitable use of all official languages as follows: ${ }^{13}$ Afrikaans, English, isiNdebele, Sesotho sa Leboa, Sesotho, siSwati, Xitsonga, Setswana, Tshivenda, isiXhosa and isizulu shall be the official South African languages at national level, and conditions shall be created for their development and for the promotion of their equal use and enjoyment.

The 1996 Constitution further states: ${ }^{14}$

The national government and provincial governments, by legislative and other measures, must regulate and monitor their use of official languages. Without detracting from the provisions of subsection (2), all official languages must enjoy parity of esteem and must be treated equitably.

In terms of section 6, a Pan South African Language Board established by national legislation is to 'promote, and create conditions for the development and use of' among others, 'all official languages.' 15

The 1996 Constitution further places a positive duty on the state to advance the use of indigenous South African languages: ${ }^{16}$

Recognising the historically diminished use and status of the indigenous languages of our people, the state must take practical and positive measures to elevate the status and advance the use of these languages.

Finally, national and provincial legislatures may pass any laws relating to functional areas listed in Schedule 4 of the 1996 Constitution,

11 Sec 6(1) of the Constitution.

$12 \mathrm{Sec} 3$ of the Interim Constitution of the Republic of South Africa, 1993 (the Interim Constitution).

$13 \mathrm{Sec} 3(1)$ of the Interim Constitution.

14 Sec 6(4) of the Constitution.

15 Sec 6(5) of the Constitution.

16 Sec 6(2) of the Constitution. See n 8 above and n 3 above, para 3.1.2. 
which include laws on language policy and the regulation of official languages. ${ }^{17}$

It is clear from these provisions that the drafters of the respective Constitutions intended for all official languages to enjoy equal status and operation post-1994. Indigenous African languages also enjoy an enhanced level of constitutional protection and attention. This article places the rights in section 6(2) in context with section 29(2) - the right to receive education in an official language or language of choice. ${ }^{18}$ Most universities currently only provide education in either English or Afrikaans. Ultimately it is argued that the adoption of indigenous languages to mediums of instruction would give effect to both section 6(2) and section 29(2). However, this is not being realised in South African universities today. It is therefore argued that in order to give effect to section 6(2) and 29(2), higher education institutions should adopt and develop indigenous African languages to mediums of instruction, thereby increasing their use and enabling teaching in these languages. In this manner, the provision in both section 6(2) and section 29(2) will be given effect to, in particular, the recognition of equal status of all official languages.

The debate on adherence to the 1996 Constitutional provisions on official languages, and in alignment with the Use of Official Languages Act, ${ }^{19}$ is an extensive and complex one. This article detracts from the complex issues raised in the administrative use of languages by government and organs of state and instead focuses on the use (and lack thereof) of official indigenous African languages in institutions of higher education.

\section{Current university language policies: analysis and criticism}

Without detracting from the arguments made above, almost every university language policy in South Africa recognises the importance of multilingualism and development of indigenous South African languages. ${ }^{20}$ While these language policies textually embody section 6 of the 1996 Constitution, as well as numerous other legislative provisions on multilingualism in South Africa, ${ }^{21}$ they detract from a materially substantive national framework on the implementation of multilingualism in the higher education sector.

17 Schedule 4 of the Constitution.

18 Sec 29(2) of the Constitution states that 'everyone has the right to receive education in the official language or languages of their choice in public educational institutions but is qualified in such instances where it is reasonably practicable'. 


\subsection{Current university language policies ${ }^{22}$}

All South African public institutions of higher education are classified according to three categories: traditional universities, comprehensive universities and universities of technology. ${ }^{23}$ Below follows a comprehensive analysis and criticism of several university language policies. The analysis is based on two aspects: Firstly, it discusses current university language policies in light of their predominant language(s) used as mediums of instruction, language(s) of communication and choice of indigenous African language identified for advancement. Statistics on student demographics at each respective institution are then analysed in the backdrop of the language discussion. ${ }^{24}$ This analysis then forms the backbone for cross analysis with provincial census statistics from the geographical location of universities in proposing implementable policy consideration for the advancement of indigenous African languages

20 See Stellenbosch University 'Language Plan of Stellenbosch University' 1-2, 5 http://www.sun.ac.za/english/Documents/Language/english_language/Languag e\%20Plan\%202014\%20Final\%2012\%20Dec\%202014-1.pdf (accessed 21 March 2016); University of Kwazulu-Natal 'Language Policy of the University of KwaZulu-Natal' paras 1.4-1.5, 5.1-5.6 http://registrar.ukzn.ac.za/Libraries/policies/Langua ge_Policy_-_CO02010906.sflb.ashx (accessed 21 March 2016); University of the Witwatersrand 'University of the Witwatersrand, Johannesburg Language Policy' $1-3$ https://www.wits.ac.za/media/migration/files/Language\%20Policy. pdf (accessed 21 March 2016); North-West University 'Institutional Language Policy of the North-West University' paras $1,2,3.2,4.1-4.2,5.1-5.2,9.1 .1 .1,9.2 .1 .1$. 9.2.1.2 http://www.nwu.ac.za/sites/www.nwu.ac.za/files/files/i-gover nancemanagement/policy/2P-2.5_Language_e.pdf (accessed 21 March 2016); University of Johannesburg 'University of Johannesburg Language Policy' paras 1, 2.4, 5.1.1 - 5.1.3, 6.1, 6.3.4 http://www.uj.ac.za/about/Documents/policies/ Language\%20Policy\%20-\%20Council\%20approved\%20-\%203\%20April\%202014.pdf (accessed 21 March 2016).

21 n 8 above.

22 Accurate at the time of writing.

23 In 2004, the higher education sector saw substantial implementation of reforms across all South African universities. Among these were the renaming of higher institutions of education to 'universities' and merging smaller universities into larger ones. Considerable mergers included but are not limited to the University of the Cape of Good Hope renamed to University of South Africa, Cape Technicon now part of Cape Peninsula University of Technology, University of Bophuthatswana and Potchefstroom University for Christian Higher Education now part of North-West University, Border Technicon, Eastern Cape Technicon, University of Transkei now part of Walter Sisulu University for Technology and Science, Technicon University merging with Rand Afrikaans University and Vista University (Soweto and East Rand Campus) to form the University of Johannesburg, Port Elizabeth Technicon and the University of Port Elizabeth now part of Nelson Mandela Metropolitan University. Notably, the Ministerial Committee Report in their guidelines for languages to be developed by the respective universities, only included traditional universities. This was subsequently changed to include universities of technology and comprehensive universities.

24 All statistics in this section were obtained from the Statistics on Post-School Education and Training in South Africa 2013 report http://www.dhet.gov.za/ DHET\%20Statistics\%20Publication/Statistics\%20on\%20Post-School\%20Education\%20 and\%20training\%20in\%20South\%20Africa\%202013.pdf (accessed 13 October 2016), as well as Statistics South Africa 2011 Census. See table 1, 2, 3, 4 \& 5 below. 
nationally. For purposes of the analysis below, only contact students are included in the statistics and it is assumed that the predominant speakers of indigenous African languages are African or black students. Tables 1 and 2 below collectively illustrate the demographics for university students and staff respectively. ${ }^{25}$

\subsubsection{University of Cape Town (UCT) ${ }^{26}$}

UCTs official language policy declares the medium of instruction and administration to be English. The policy states that English is an international language of communication in science and business, although it is not the primary language for many of its students and staff. ${ }^{27}$ A major objective of the language policy plan is to ensure students acquire effective literacy in English. ${ }^{28}$ The policy's only mention of multilinguism refers to its awareness and proficiency with the aid of language and literature departments 'to explore and implement ways in which these aims may be achieved through the Undergraduate and Postgraduate Programme structures'. ${ }^{29}$ Finally, students intending to study at the institution must have a certain level of proficiency in English and are required to submit evidence (Matric or Senior Certificate) of this as part of their application to study, whether on an undergraduate or postgraduate level. ${ }^{30}$

Seemingly, UCT has no official stance on the incorporation of an official indigenous African language within its functioning. The Ministerial Committee Report outlined isiXhosa and Sesotho as possible indigenous languages to be taken up by UCT for advancement. UCTs student demographics show that black students constitute $33 \%$ of the total student population. Black ${ }^{31}$ academic staff account for only $29 \%$ of the total permanent number of academic staff.

\subsubsection{University of the Free State (UFS) ${ }^{32}$}

Until March 2016, UFSs main languages of instruction and communication were English and Afrikaans. Recent developments at

25 See Tables 1 \& 2 on pages 11 \& 12 below.

26 University of Cape Town 'University of Cape Town Language Policy', https:// www.uct.ac.za/downloads/uct.ac.za/.../policies/languagepolicy.doc (accessed 21 March 2016).

27 University of Cape Town (n 26 above) 1.

28 As above.

29 As above.

30 University of Cape Town (n 26 above) 1 - 2.

31 'Black' academics, in terms of the Statistics on Post-School Education and Training in South Africa report (n 24 above) includes all African, Coloured, Indian and Asian academics employed on a permanent contract.

32 University of the Free State 2003 'Language Policy of the University of the Free State', approved by Council: 6 June 2003. Adopted but currently under revision. 
the institution have seen the university amend its language policy, removing Afrikaans as a medium of instruction. ${ }^{33}$ UFSs language policy illustrates the removal of Afrikaans as an argument for 'inclusivity' at universities. Instead of adopting an indigenous South African language, UFS revised its language policy in 2016 making English its only medium of instruction at the institution from 2017 onward. This shows an increasingly exclusive English policy being implemented in higher education institutions, even in the case of a former historically Afrikaans university (HAU). ${ }^{34}$ In addition, English is also becoming the main language of research, community service, management and administration. ${ }^{35}$ The 'Anglicisation' of institutions of higher education has, at the same time, meant that indigenous African languages are not meaningfully developed as mediums of instruction or communication. ${ }^{36}$ UFSs lack of planning for the advancement of an indigenous African language means that the $62 \%$ majority of its black students studying at the institution have no other option but to study in English. Black academic staff at UFS make up for only $23 \%$ of all permanent academic staff.

\subsubsection{University of KwaZulu-Natal (UKZN) $)^{37}$}

UKZN, in its language policy, recognises the need to develop and promote the proficiency of official languages, in particular English and isizulu. The policy clearly indicates its objective to develop awareness of multilinguism through the acknowledgement of the predominant languages spoken within the province, namely, isizulu, English and Afrikaans. ${ }^{38}$ The policy states that English is its primary academic language but that it would activate the development and use of isizulu as an additional medium of instruction. ${ }^{39}$ It further adds that its implementation of the policy 'forms part of a wider interconnected strategy at the national level to promote multilinguism and, at the provincial level, to advance isizulu' ${ }^{40}$ In developing isiZulu as an indigenous language, UKZN undertakes to pay

33 S Jamal 'Vrystaat goes English' http://www.timeslive.co.za/thetimes/2016/03/ 15/Vrystaat-goes-English (accessed 17 March 2016).

34 The former HAUs, Rand Afrikaans University, University of the Free State, University of Pretoria, University of Potchefstroom and Stellenbosch University, were previously predominantly Afrikaans universities.

35 V Webb (2006) English in Higher Education in South Africa: inclusion or exclusion MIDP Symposium, Bloemfontein, 24 - 27 April 20061.

36 As above.

37 Language Policy of the University of KwaZulu-Natal (n 20 above).

38 UKZNs choice in these languages is not fully justified, particularly its mention of Afrikaans as a predominant language within the province. Census data from Statistics South Africa shows that isizulu is the predominant language spoken as a first language by $77.8 \%$ of the province's population, followed by English and isiXhosa. Afrikaans first language speakers only account for $1.6 \%$ of the province's population.

39 Language Policy of the University of KwaZulu-Natal (n 20 above) 1.

40 Language Policy of the University of KwaZulu-Natal (n 20 above) 2. 
particular attention to curriculum development in isiZulu, work alongside the University of Zululand to create a regional platform for the development and study of isizulu, and encourage research at UKZN to be conducted in isiZulu. ${ }^{41}$

Although the language policy remains somewhat silent on the implementation process of isizulu at the university, its language policy is seemingly one of the stronger ones in existence today. Identifying isizulu as an indigenous language to be adopted also follows the Ministerial Committee Report on its suggestion for adoption of isizulu. ${ }^{42}$ The adoption of isiZulu was also suggested for the University of Johannesburg, North-West University, University of South Africa, University of the Witwatersrand and the University of Zululand. ${ }^{43}$

At UKZN, $64 \%$ of the student population is black and $55 \%$ of its total academic staff are also black. However, even in a seemingly well transformed university such as UKZN, more effort is needed in terms of indigenous language education. ${ }^{44}$

\subsubsection{Central University of Technology, Free State (CUT) $)^{45}$}

All teaching and learning facilitation, as well as correspondence, general communication and institutional transactions at CUT are conducted in English. ${ }^{46}$ CUTs language policy states that it does not prescribe the language of communication between the instructional employee (academic staff) and student but rather assumes the choice of language is determined by mutual agreement. ${ }^{47}$ It adds where a student's competence in English would constitute a serious communication barrier that could be resolved by using the student's home language, use of such home language is recommended. The policy however states that this is not a legal obligation in the event that CUT cannot provide assistance to students in their home languages. ${ }^{48}$ The only specific mention of the advancement of indigenous African languages regards the multilingual lexicons of concepts and terminology. Within feasibility limitations, student

41 Language Policy of the University of KwaZulu-Natal (n 20 above) 3.

42 Ministerial Committee Report (n 5 above) para 48.6.

43 As above.

44 DE Mutasa 'Language Policy Implementation in South African Universities vis-à-vis the Speakers of Indigenous African Languages' Perception' (2015) 31 Per Linguam 50.

45 Language Policy of the Central University of Technology, Free State, implemented on 1 January 2010 (CUT Policy).

46 Language Policy of the Central University of Technology (n 45 above) para 13.1.4.1.

47 Language Policy of the Central University of Technology (n 45 above) para 13.1.4.1.4.

48 Language Policy of the Central University of Technology (n 45 above) para 13.1.4.1.5. 
support will be extended to Sesotho first language speakers in this form of support. ${ }^{49}$ CUTs language policy seemingly has no explicit implementation plan for the adoption of Sesotho as an indigenous language. The Ministerial Committee Report identified Sesotho as a possible language of development at CUT and UFS. At $87 \%$, the CUT student population has the largest number of black students in any institution. $46 \%$ of CUTs permanent academic staff are black. There is clear indication that an indigenous language at CUT is in demand and a comprehensive plan for the adoption of Sesotho is recommended. ${ }^{50}$

\subsubsection{University of Johannesburg (UJ) $)^{51}$}

Informed by its geographical context, Sepedi, English, isiZulu and Afrikaans are designated primary languages used at UJ. ${ }^{52}$ However, English is the predominant language of instruction and only where it is possible and practical, will the other three primary languages be used. ${ }^{53}$ isiZulu and Sepedi were both identified as possible languages to be advanced by UJ in the Ministerial Committee Report. ${ }^{54} 87 \%$ of UJ's student population is black and $43 \%$ of permanent academic staff are black.

\subsubsection{Nelson Mandela Metropolitan University (NMMU) ${ }^{55}$}

NMMU uses English as its predominant language of tuition and assessment. Its language policy states that at the same time, it embraces the imperative to advance isiXhosa at the institution, and ensure the retention and strengthening of Afrikaans as an established academic language. The choice of isiXhosa adheres to the Ministerial Committee Report. 59\% of the student population is black yet there is no definitive plan for the adoption of isiXhosa as a medium of instruction.

\subsubsection{North-West University (NWU) ${ }^{56}$}

NWUs language policy states English, Afrikaans and Setswana to be official languages, with Sesotho having 'working-language status' use at its Vaal Triangle Campus. ${ }^{57}$ Presently, only English and Afrikaans

49 Language Policy of the Central University of Technology (n 45 above) para 13.1.4.1.6.

50 Language Policy of the Central University of Technology (n 45 above)

51 University of Johannesburg Language Policy (n 20 above).

52 University of Johannesburg Language Policy (n 20 above) para 5.

53 Language Policy of the Central University of Technology (n 45 above) para 6.2.1.

54 Ministerial Committee Report (n 5 above) para 48.7.

55 Nelson Mandela Metropolitan University Language and Multilingual Development Support.

56 Institutional Language Policy of the North-West University (n 20 above). 
are used as mediums of instruction, while efforts to implement Setswana and Sesotho are being made. ${ }^{58}$ The Ministerial Committee Report suggested Setswana and isizulu as ideal indigenous languages the university should adopt. Instead, NWUs language policy refers to Setswana and Sesotho as its choice of adoption and integration of indigenous languages. Half of the student population at NWU is black, with only $27 \%$ of the total permanent academic staff being black. The university's comparatively large (45\%) white population may strengthen it in retaining Afrikaans as a medium of instruction, however, its lack in implementation of Setswana is not justifiable in terms of student demographics.

\subsubsection{University of Pretoria (UP) $)^{59}$}

UP uses English and Afrikaans as its official languages of instruction. ${ }^{60}$ The university has identified Sepedi as an indigenous language to be promoted, in particular, and is used as a third language of communication. ${ }^{61}$ The Ministerial Report identified Sepedi, Setswana and IsiNdebele as possible indigenous African language for advancement at UP. UP, alongside UCT and SU, are the only three universities in the country which still maintain a higher white than black student population. Student demographics show that $42 \%$ of the student population is black and $51 \%$ are white. Further to this, only $22 \%$ of the permanent academic staff are black. UP also lacks an implementable plan on the adoption of Sepedi at the institution. By implication, education through an official indigenous language at UP is seemingly not a priority at the institution. ${ }^{62}$ Instead, the university focuses on academic excellence and achievement through already established academic languages, namely English and Afrikaans. ${ }^{63}$ This too means that indigenous languages will, for the meantime, remain on the side-lines at UP. ${ }^{64}$ On 22 June 2016, UPs Council adopted a new language policy in which English would be the primary language of instruction. ${ }^{65}$ The new language policy further aims to develop Sepedi

57 Institutional Language Policy of the North-West University (n 20 above) para 3.2.

58 Institutional Language Policy of the North-West University (n 20 above) para 9.1.2.1.

59 University of Pretoria 'University of Pretoria Language Policy' http:// www.up.ac.za/media/shared/Legacy/sitefiles/file/1/elzanie/ r1610languagepolicy.pdf (accessed 21 March 2016).

60 University of Pretoria Language Policy (n 59 above) para 1.

61 University of Pretoria Language Policy (n 59 above) para 3.1.

62 Mutasa (n 44 above) 49.

63 As above. Further University of Johannesburg Language Policy (n 20 above) para 3.3.

64 As above.

65 X Janse van Rensburg \& M Svicevic 'UP to become English only from 2017' http: // perdeby.co.za/sections/news/tuks-news/4992-up-to-become-english-only-from2017 (accessed 21 August 2016). 
to a higher language of discourse, although it is not certain whether the new policy includes any implementation plans.

\subsubsection{Rhodes University $(R U)^{66}$}

The university's langue of teaching and learning is English. All official university business is also conducted in English. ${ }^{67}$ RUs policy states that RU will create conditions for the use of isiXhosa as a language of learning and eventually also teaching. ${ }^{68}$ RUs language policy states that selected signage will be in English, Afrikaans and isiXhosa. The language policy goals further state that the language of wider communication at RU is English but translation and interpretation into isiXhosa and Afrikaans is provided for students and staff where necessary and feasible. ${ }^{69}$ The policy adds that RU seeks to develop isiXhosa as a language to support the language of teaching and learning. ${ }^{70}$ In line with the Ministerial Committee Report, RU was identified as an institution of higher education for the advancement of isiXhosa, alongside seven other institutions. The RU student population consists of $54 \%$ black students. The language policy is plausible, but lacks an implementation plan regarding the advancement of IsiXhosa. ${ }^{71}$

\subsubsection{University of South Africa (Unisa) ${ }^{72}$}

Unisa, in the context of this paper, differs in that its academic plan is offered to distance students and not contact students. Unisa's language of instruction is based on functional multilinguism which it defines as the choice of a particular language being used depends on the particular situation and context it is to be used in. English is however offered across the board as an academic language. Unisa was identified as the optimal university for the advancement of all official languages by the Ministerial Committee Report. As per the 2016 amendment of the language policy, an implementation plan will ensure annual evaluation and reporting to Senate, with a reevaluation of the policy set to take place in 2020.

66 Rhodes University 'Rhodes University Language Policy' https://www.ru.ac.za/ media/rhodesuniversity/content/institutionalplanning/documents/

Language\%20Policy.pdf (accessed 21 March 2016)

67 Rhodes University Language Policy (n 66 above) para 2.1.

68 As above.

69 Rhodes University Language Policy (n 66 above) para 2.2.

70 Rhodes University Language Policy (n 66 above) para 3C.

71 Mutasa (n 44 above) 50 .

72 Unisa Language Policy, approved by Council on 22 September 2006, revised on 19 November 2010 and 28 April 2016. 


\subsubsection{Stellenbosch University (SU) ${ }^{73}$}

SU uses Afrikaans as its predominant language of instruction. The university offers several variations to languages used as mediums of instruction. Parallel-mediums teaching, teaching in Afrikaans with interpretation into English and teaching in English with interpretation into Afrikaans are currently options present at SU. SUs language policy further states that isiXhosa is used as an institutional language, depending on circumstances. ${ }^{74}$ In its planned advancement of isiXhosa, SU states that it presents modules in programmes and short courses as well as developing trilingual terminologies in various disciplines. ${ }^{75} \mathrm{SU}$ also states that in environments which communicate regularly to the public and students, SU ensures that there are enough staff members who can communicate with ease in English and isiXhosa. ${ }^{76}$ Student demographics show that only $23 \%$ of the student population is black. The predominant race group consists of white students. This may be due justification for Stellenbosch retaining Afrikaans as a language of instruction, with the possible adoption of isiXhosa as an indigenous language.

\subsubsection{University of the Western Cape $(U W C)^{77}$}

The languages used when writing tasks, assignments, tests and examinations is English. According to UWCs language policy, English and isiXhosa should be used in setting up of tasks, assignments, tests and examinations and wherever it is practicable. ${ }^{78}$ All students and staff are encouraged to develop proficiency in Afrikaans, English and isiXhosa. UWCs predominant language of tuition is English, while lecturers who are competent in other languages are encouraged to use those languages in addition to the main language of teaching. ${ }^{79}$ UWCs student population comprises of $42 \%$ black students while $62 \%$ of all permanent academic staff are black. in 2016.

74 Language Plan for Stellenbosch University (n 73 above) para 6.1.b.

75 Language Plan for Stellenbosch University (n 73 above) para 5.

76 Language Plan for Stellenbosch University (n 73 above) para 6.1.g.

77 University of Western Cape 'University of Western Cape (UWC) Language Policy' https://www.uwc.ac.za/Documents/Language_Policy_C2003-3.pdf (accessed 21 March 2016).

78 University of Western Cape (UWC) Language Policy (n 77 above) para 4.

79 University of Western Cape (UWC) Language Policy (n 77 above) para 3. 


\subsubsection{University of Witwatersrand (Wits) ${ }^{80}$}

Wits' language policy recognises the importance of multilinguism particularly in accordance with its geographical location. It states that its location means that 76 home languages are spoken by its students and staff. Sesotho and isizulu are the most widely understood African language spoken in the immediate vicinity of the university. ${ }^{81}$ The language policy however states that it believes institutions in KZN are more suited to develop isiZulu and that in should predominantly focus on the advancement of Sesotho. ${ }^{82}$ Although English remains the only medium of instruction at the institution, Wits' language policy outlines a detailed four phase plan for the implementation of Sesotho and its eventual use as a medium of instruction. ${ }^{83}$ The language policy further includes rationale for its choice of Sesotho, as well as a more unified and congruent claim for its development, with consideration for other languages being developed at other institutions. ${ }^{84}$ This rationale adheres well with the Ministerial Committee Report. Wits' language policy is arguably the most progressive and well informed language policy amongst higher education institutions, taking into account student demographics, provincial census, development of indigenous languages holistically and institutional co-operation in its choice of languages for advancement. 58\% of the Wits student population is black, yet only $38 \%$ of total permanent academic staff are black.

Table 1 below is a brief overview of student demographic populations across universities in South Africa. It serves to show the large number of black students attending universities, indicating a possible demand for receiving education in indigenous languages.

80 University of the Witwatersrand, Johannesburg Language Policy (n 20 above).

81 University of the Witwatersrand, Johannesburg Language Policy (n 20 above) 1.

82 As above.

83 University of the Witwatersrand, Johannesburg Language Policy (n 20 above) 1 2. Further see para 3.2. below.

84 University of the Witwatersrand, Johannesburg Language Policy (n 20 above) 3 6. 
Table 1: Number of students enrolled in higher education institutions, by population group and institution, in $2013^{85}$

\begin{tabular}{|c|c|c|c|c|}
\hline \multirow[t]{2}{*}{ Institution } & \multicolumn{3}{|c|}{$\begin{array}{l}\text { Demographics for Contact } \\
\text { Students }\end{array}$} & \multirow[b]{2}{*}{ Total } \\
\hline & African & Coloured & White & \\
\hline Cape Peninsula University of Technology & 19235 & 9367 & 4372 & 33370 \\
\hline University of Cape Town & 6979 & 3628 & 8589 & 26109 \\
\hline $\begin{array}{l}\text { Central University of Technology, Free } \\
\text { State }\end{array}$ & 11411 & 434 & 1163 & 13050 \\
\hline Durban University of Technology & 21053 & 415 & 827 & 26059 \\
\hline University of Fort Hare & 11714 & 229 & 327 & 12315 \\
\hline University of the Free State & 15860 & 1344 & 8100 & 25611 \\
\hline University of Johannesburg & 38648 & 1500 & 6043 & 48386 \\
\hline University of KwaZulu-Natal & 26055 & 906 & 2796 & 40576 \\
\hline University of Limpopo & 22478 & 26 & 278 & 22914 \\
\hline Mangosuthu University of Technology & 11340 & 16 & 5 & 11375 \\
\hline Nelson Mandela Metropolitan University & 14941 & 3634 & 6407 & 25301 \\
\hline North-West University & 18176 & 1143 & 16434 & 36195 \\
\hline University of Pretoria & 20038 & 1069 & 24089 & 47468 \\
\hline Rhodes University & 4046 & 280 & 2856 & 7485 \\
\hline University of South Africa & 0 & 0 & 0 & 0 \\
\hline Stellenbosch University & 4231 & 4421 & 18130 & 27418 \\
\hline Tshwane University of Technology & 49290 & 304 & 3057 & 52864 \\
\hline University of Venda & 11797 & 3 & 7 & 11818 \\
\hline Vaal University of Technology & 19647 & 268 & 508 & 20495 \\
\hline Walter Sisulu University & 23970 & 37 & 43 & 24122 \\
\hline University of Western Cape & 8653 & 9431 & 1021 & 20382 \\
\hline University of Witwatersrand & 18210 & 1157 & 7669 & 31134 \\
\hline University of Zululand & 16466 & 26 & 44 & 16591 \\
\hline Total & 394238 & 39638 & 112765 & 581038 \\
\hline Percentage & 68 & 7 & 19 & 100 \\
\hline
\end{tabular}

Table 1: Adapted from the 4th issue of the Statistics on Post-School Education and Training in South Africa. 86

852013 HEMIS Database, extracted in October 2014 (available at http://www. dhet.gov.za/DHET\%20Statistics\%20Publication/Statistics\%20on\%20Post-School\%20 Education\%20and\%20Training\%20in\%20South\%20Africa\%202013.pdf).

86 Interpretation notes: Table 1 only accounts for contact students who are defined as those students who are registered mainly for courses offered in contact mode. Data from the University of Mpumalanga and Sol Plaatjie University are not included as these universities were founded after 2013. Figures for Unisa have been omitted as it only conducts its business through distance learning. 
Table 2: Adapted from the 4th issue of the Statistics on PostSchool Education and Training in South Africa. ${ }^{87}$ Number and percentage of permanent staff in higher education institutions, by population group and institution, in 2013.88

Table 2 below is a brief overview of staff demographics across universities in South Africa. It serves to show the limited number of black academic staff working at universities. This is detrimental in that such staff would be more competent in indigenous African languages. With such low numbers this translates negatively to universities having staff competent in such languages.

\begin{tabular}{|l|l|l|l|l|}
\hline & \multicolumn{3}{|l|}{ Total permanent staff } & \multicolumn{2}{l|}{$\begin{array}{l}\text { Percentage of black } \\
\text { staff in total }\end{array}$} \\
\hline & $\begin{array}{l}\text { Instruction } \\
\text { and } \\
\text { research } \\
\text { staff }\end{array}$ & $\begin{array}{l}\text { Admin } \\
\text { Staff }\end{array}$ & $\begin{array}{l}\text { Instruction } \\
\text { and } \\
\text { research } \\
\text { staff }\end{array}$ & $\begin{array}{l}\text { Admin } \\
\text { Staff }\end{array}$ \\
\hline $\begin{array}{l}\text { Cape Peninsula University of } \\
\text { Technology }\end{array}$ & 768 & 973 & 60 & 84 \\
\hline University of Cape Town & 1093 & 2233 & 29 & 71 \\
\hline $\begin{array}{l}\text { Central University of Technology, } \\
\text { Free State }\end{array}$ & 291 & 342 & 46 & 64 \\
\hline Durban University of Technology & 579 & 767 & 73 & 91 \\
\hline University of Fort Hare & 327 & 520 & 72 & 89 \\
\hline University of the Free State & 962 & 1165 & 23 & 35 \\
\hline University of Johannesburg & 1024 & 1894 & 43 & 68 \\
\hline University of KwaZulu-Natal & 1376 & 2104 & 55 & 85 \\
\hline University of Limpopo & 884 & 725 & 85 & 84 \\
\hline $\begin{array}{l}\text { Mangosuthu University of } \\
\text { Technology }\end{array}$ & 195 & 263 & 90 & 96 \\
\hline $\begin{array}{l}\text { Nelson Mandela Metropolitan } \\
\text { University }\end{array}$ & 606 & 993 & 27 & 58 \\
\hline North West University & 1288 & 1809 & 27 & 32 \\
\hline University of Pretoria & 1300 & 1598 & 22 & 48 \\
\hline Rhodes University & 351 & 547 & 25 & 56 \\
\hline University of South Africa & 1631 & 3137 & 50 & 72 \\
\hline
\end{tabular}

87 Interpretation notes: Institutional and research staff (academic staff) are those staff that spend more than $50 \%$ of their official time on duty on instruction and research activities. Administrative staff includes all executive, professional, technical and office staff that spends less than $50 \%$ of their official time on duty on instruction and research activities. The 'percentage of black staff in total' includes all African, Coloured, Indian and Asian (non-white) staff employed on a permanent contract.

882013 HEMIS database, extracted in October 2014. 


\begin{tabular}{|l|l|l|l|l|}
\hline Stellenbosch University & 1006 & 1909 & 21 & 48 \\
\hline Tshwane University of Technology & 917 & 1468 & 56 & 74 \\
\hline University of Venda & 337 & 319 & 93 & 99 \\
\hline Vaal University of Technology & 361 & 444 & 61 & 75 \\
\hline Walter Sisulu University & 576 & 671 & 87 & 96 \\
\hline University of Western Cape & 574 & 928 & 62 & 94 \\
\hline University of Witwatersrand & 1093 & 1479 & 38 & 74 \\
\hline University of Zululand & 299 & 379 & 81 & 92 \\
\hline Total & 17838 & 26667 & 47 & 68 \\
\hline
\end{tabular}

From tables 1 and 2, and upon analysis of the abovementioned university language policies, two aspects are evident. Firstly, university language policies may seem substantively comprehensive and well drafted, but they are difficult to implement. This, as Van Huyssteen ${ }^{89}$ and Nkuna90 critically note, shows a gap between university language policies and the implementation thereof. ${ }^{91}$ Secondly, upon the completion and presentation of the Ministerial Committee Report on the development of indigenous African languages, all institutions of higher education were compelled to choose and promote indigenous African languages in such institutions. ${ }^{92}$

All higher education institutions are required to develop their own language policy subject to the above policy framework, which should be submitted to the Minister by 31 March 2003. The Ministry will continue to monitor the impact of language policy in higher education.

Evidently, no effective binding national framework for the advancement of African indigenous official languages among institutions of higher education was concluded. This resulted in several blunders for the advancement of indigenous South African languages at universities. Universities have either dismally failed at promoting and advancing an indigenous South African language due to ineffective or inefficient implementation of language policies. Some were left to decide for their own which indigenous South African

89 L Van Huyssteen 'A practical approach to the standardization and elaboration of Zulu as a technical language' unpublished thesis, University of South Africa, 2003 22.

$90 \mathrm{PH}$ Nkuna 'The fit between government language policies and institutional language policies: the case of indigenous languages in the South African higher education system' unpublished thesis, University of South Africa, 2010250.

91 Implementation in this regard means the effective use of languages as a medium of instruction and of communication.

92 Ministerial Committee Report (n 5 above) para 48.8. Further see South Africa (1997) Ministry of Education 'Education White Paper 3' Government Gazette 1196 para $2.80-2.81$. 
languages to choose which, resulted in several universities choosing the same indigenous languages, leaving other languages completely excluded. Several universities in their language policy documents may even boast of having more than one indigenous official language as a medium of instruction or language of communication. This individual linguistic autonomy has, for the greater part, detracted from successful implementation of indigenous languages in these institutions. A country's language policy is a set of principles conceptualised in an overreaching framework and requires congruency for effective implementation. ${ }^{93}$ Although the guideline for the advancement of indigenous languages in universities was drawn up in the Ministerial Committee Report, it was not binding on universities and in focusing on regional adoption of indigenous languages by universities, it detracted from congruency and national advancement of such languages. ${ }^{94}$

\section{Implementable policy considerations}

\subsection{Building on the 2005 Ministerial Committee Report ${ }^{95}$}

With the above-mentioned in mind, and bearing particular attention to a strategic national framework for the advancement of indigenous South African languages, several implementable policy considerations are discussed. Prior to the discussion on implementable policy considerations, the following must too be noted:

Firstly, although the majority of historically white, Afrikaans universities are gradually moving to the adoption of single-medium (English) languages of instruction, language continues to be a barrier to some in accessing these institutions. ${ }^{96}$ Secondly, the change in the demographics of student populations at universities does not necessarily translate to these institutions being more representative. ${ }^{97}$ Thirdly, there is still a broad difference in the number of black and white graduation rates, suggesting that white student graduation rates are double that of those for black students. ${ }^{98}$ Fourthly, the growth in black student numbers has been accompanied by a decline in white student enrolment numbers. ${ }^{99}$

93 Van Huyssteen (n 89 above) para 18. See TG Reagan Language Matters: Reflections on Educational Linguistics (2009) 134.

94 Unpublished: RA Judith 'The Implementation of the Language Policy at Tshwane University of Technology: The Case of Indigenous Languages' unpublished MA (African Languages) dissertation, University of South Africa, 201412 http:// hdl.handle.net/10500/18665 (accessed 16 February 2016).

95 Language Policy for Higher Education report (n 4 above) para 5.

96 'Transformation and Restructuring: A new institutional landscape for higher education' Government Notice 885 (2002) 34. Further see National Plan for Higher Education, Ministry of Education (2001) 37.

97 'National Plan for Higher Education' Ministry of Education (2001) 38.

98 As above.

99 As above. 
Fifthly, pragmatically speaking, it is impossible to incorporate all 11 official languages as mediums of instruction at every university in the country. Sixthly, every public university should be legislatively required to adopt at least one indigenous South African language, with a mind-set of: 100

(a) a multi-phased implementation plan;

(b) which includes a set period for its implementation;

(c) with a final outcome of advancing such indigenous language to be used as a medium of instruction at the institution.

\subsection{The geographical location of universities and the choice in adoption of indigenous African languages}

University languages of instruction are usually the official or majority languages. ${ }^{101}$ The need for education in mother-tongue instruction (indigenous African languages) is an exhaustive argument on its own. ${ }^{102}$ Studies have shown the effectiveness mother-tongue education plays in particular, being beneficial to language competence in the first language as well as achievement in other subject areas and training in a second language. ${ }^{103}$ According to the Ministerial Committee Report and based on the United Nations Educational, Scientific and Cultural Organisation's Education Position Paper, ${ }^{104}$ mother-tongue, or in this case, education in an indigenous language is effective if four requirements are met. Firstly, appropriate terminology for education purposes must exist, secondly, sufficient resource material is available, thirdly, appropriately trained teachers are available, and fourthly, there is willingness from learners, teachers and parents for education in indigenous languages. ${ }^{105}$

The need for the development of indigenous African languages can be explained by Foley as follows: at the moment, English, and to a lesser extent, Afrikaans, are the only languages capable of functioning fully as languages of learning and teaching at higher education institutions, yet most current and potential higher education students are not sufficiently fluent in English and or Afrikaans to be able to study effectively through these languages. ${ }^{106}$

100 Ministerial Committee Report (n 5 above) para 48.1 - 48.8.

101 Ministerial Committee Report (n 5 above) para 20.

102 This paper detracts from this such discussion as the advancement of indigenous languages is based on its constitutional upholding.

103 UNESCO 'Education in a multilingual world' 15-16. Education Position Paper, Paris, France. http://unesdoc.unesco.org/images/0012/001297/129728e.pdf (accessed 26 March 2016).

104 As above. Further see Ministerial Committee Report (n 5 above) para 22

105 As above.

106 A Foley 'Language policy for higher education in South Africa: implications and complications' (2004) 18 (1) South African Journal of Higher Education 57. Further see Language Policy for Higher Education report (n 4 above). 
Where advancement of indigenous languages in institutions of higher education regards, the Ministerial Committee Report stated 'each higher education institution should be required to identify an indigenous African language of its choice for initial development as a medium of instruction.'107

In identifying an African indigenous language, universities were given a criterion of seven priorities to include in consideration. These are: regional and locality-specific criteria, concentration of speakers and students, availability of expertise, availability of infrastructure, affordability, possible linkages and partnerships with English and Afrikaans, economic, social and political significance of courses. ${ }^{108}$ Table 3 below illustrates the Ministerial Committee Report recommendations on recommended languages each respective institution should consider in adopting for advancement and eventually using such languages as a medium of instruction.

Table 3: The 2005 Ministerial Committee Report guidelines for choice of indigenous languages to be adopted by institutions of higher education. ${ }^{109}$

\begin{tabular}{|l|l|}
\hline Indigenous Languages & University \\
\hline isiNdebele & UP, UNISA \\
\hline isiZulu & UJ, UKZN, UNW, UNISA, WITS, UZ \\
\hline isiXhosa & UCT, UFH, UFS, NMMU, RU, SU, UNISA, \\
\hline UWC \\
\hline Sepedi (SeSotho sa Lebowa) & UL, UJ, UP, UNISA, UV \\
\hline SeTswana & UCT, UFS, SU, UNISA, WITS \\
\hline siSwati & UWN, UP, UNISA \\
\hline TshiVenda & UNISA, UZ \\
\hline XiTsonga & UL, UNISA, UV \\
\hline
\end{tabular}

Table 3: Adapted from the Ministerial Committee Report.

Although the recommendations are necessary, they are not fool proof. In this regard, the following are additional considerations which must be borne in mind:

(a) current student population and demographics at each institution, particularly focused on the number of black students as speakers of indigenous languages;

107 Ministerial Committee Report (n 5 above) para 48.5.

108 Education White Paper 3 (n 92 above); Ministerial Committee Report (n 5 above) para 48.3.

109 Although initially not specified, Table 3 includes traditional universities alongside universities of technology and comprehensive universities. 
(b) geographical location of each institution with regard to its feed area;

(c) predominant languages spoken in the vicinity or province of the institution;

(d) current staff population and demographics, particularly of black staff competent in indigenous languages;

(e) availability of infrastructure;

(f) affordability;

(g) holistic envisagement as not to detract from a national framework for the

advancement of indigenous languages.

For purposes of this article, only points $\mathrm{a}, \mathrm{b}, \mathrm{c}$ and $\mathrm{d}$ are discussed and applied to individual universities when considering the most appropriate indigenous African language which should be adopted. The statement plan can be summarised as follows: a university should adopt an indigenous African language, while cognisant of all the consideration mentioned here, with the outlook of using such language as a medium of instruction, while ensuring national congruency in advancing all nine official indigenous languages. Table 4 below lists the nine provinces alongside universities located in each province and the predominant languages spoken as first languages in each province.

Table 4: List of provinces with universities within each province and most prominent first languages spoken in that province $^{110}$

\begin{tabular}{|l|l|l|}
\hline Province & Universities in province & $\begin{array}{l}\text { Percentage of population per } \\
\text { province by first language } \\
\text { speakers }\end{array}$ \\
\hline Gauteng (GP) & $\begin{array}{l}\text { UJ, UP, UNISA, TUT, } \\
\text { WITS, VUT }\end{array}$ & $\begin{array}{l}\text { IsiZulu (19.8\%) English (13.3\%) } \\
\text { Afrikaans (12.4\%) Sesotho (11.6\%) } \\
\text { Sepedi (10.6\%) Setswana (9.1\%) }\end{array}$ \\
\hline Limpopo (LP) & UV, UL & $\begin{array}{l}\text { Sepedi (52.9\%) Xitsonga (17.0\%) } \\
\text { Tshivenda (16.7\%) }\end{array}$ \\
\hline Mpumalanga (MP) & $\begin{array}{l}\text { University of } \\
\text { Mpumalanga }\end{array}$ & $\begin{array}{l}\text { SiSwati (27.7\%) isiZulu (24.1\%) } \\
\text { Xitsonga (10.4\%) isiNdebele } \\
(10.1 \%)\end{array}$ \\
\hline
\end{tabular}

110 Table 4 interpretation notes: All statistics obtained from Statistics South Africa census 2011. A full list of abbreviations can be found at the end of this article. 


\begin{tabular}{|l|l|l|}
\hline North West (NW) & NWU & $\begin{array}{l}\text { Setswana (63.4\%) Afrikaans } \\
(9.0 \%) \text { Sesotho (5.8\%) isiXhosa } \\
(5.5 \%) \text { Xitsonga (3.7\%) English } \\
(3.5 \%)\end{array}$ \\
\hline KwaZulu-Natal (KZN) & DUT, MUT, UZ, UKZN, & $\begin{array}{l}\text { IsiZulu (77.8\%) English (13.2\%) } \\
\text { isiXhosa (3.4\%) Afrikaans (1.6\%) }\end{array}$ \\
\hline Northern Cape (NC) & Sol Plaatjie & $\begin{array}{l}\text { Afrikaans (53.8\%) Setswana } \\
(33.1 \%) \text { isiXhosa (5.3\%) English } \\
(3.4 \%)\end{array}$ \\
\hline Western Cape (WC) & CPUT, UCT, SU, UWC & $\begin{array}{l}\text { Afrikaans (49.7\%) isiXhosa (24.7\%) } \\
\text { English (20.2\%) Sesotho (1.1\%) }\end{array}$ \\
\hline Eastern Cape (EC) & NMMU, UFH, RU, WSU & $\begin{array}{l}\text { IsiXhosa (78.8\%) Afrikaans (10.6\%) } \\
\text { English (5.6\%) Sesotho (2.5\%) }\end{array}$ \\
\hline Free State (FS) & UFS, CUT & $\begin{array}{l}\text { Sesotho (64.2\%) Afrikaans (12.7\%) } \\
\text { isiXhosa (7.5\%) Setswana (5.2\%) } \\
\text { isiZulu (4.4\%) English (2.9\%) }\end{array}$ \\
\hline
\end{tabular}

It is evidently clear that some provinces are home to more universities than others. It is suggested that where a province has several universities, the language with the most speakers in that province should be assigned to larger universities with a greater functional capacity. These universities should be required to choose the most predominant languages as these universities can accommodate the larger number of speakers of the language who are assumed to be prospective and current students of such universities. 
Table 5: The nine official indigenous languages with the suggested universities to adopt each language for advancement as a medium of instruction, based on provincial demographics ${ }^{111}$

\begin{tabular}{|c|c|c|c|}
\hline Language & $\begin{array}{l}\text { Ministerial } \\
\text { Committee } \\
\text { institution } \\
\text { suggestion }\end{array}$ & $\begin{array}{l}\text { Institution } \\
\text { suggestions based on } \\
\text { provincial } \\
\text { demographics }\end{array}$ & Rationale \\
\hline isiZulu & $\begin{array}{l}\text { UJ, UKZN, UNW, } \\
\text { UNISA, WITS, UZ }\end{array}$ & $\begin{array}{l}\text { UKZN* }^{*}, \text { DUT}^{*}, \text { UZ}^{*}, \text { UJ, } \\
\text { WITS, VUT, TUT }\end{array}$ & $\begin{array}{l}\text { KZN (77.8\%), GP } \\
(19.8 \%)\end{array}$ \\
\hline isiXhosa & $\begin{array}{l}\text { UCT, UFH, UFS, } \\
\text { NMMU, RU, SU, } \\
\text { UNISA, UWC }\end{array}$ & $\begin{array}{l}\text { UFH*, NMMU*, RU*, } \\
\text { WSU, CPUT, UCT, } \\
\text { UWC, SU }\end{array}$ & $\begin{array}{l}\text { EC (78.8\%), WC } \\
(24.7 \%)\end{array}$ \\
\hline isiNdebele & UP, UNISA & $\begin{array}{l}\text { University of } \\
\text { Mpumalanga }\end{array}$ & MP (10.1\%) \\
\hline Sepedi & $\begin{array}{l}\text { UL, UJ, UP, } \\
\text { UNISA, UV }\end{array}$ & UV, UL, UP & LP (52.9\%) \\
\hline Xitsonga & UL, UNISA, UV & $\begin{array}{l}\text { University of } \\
\text { Mpumalanga, } \mathrm{UV}^{*}, \mathrm{UL}^{*}\end{array}$ & $\begin{array}{l}\text { MP (10.4\%), LP } \\
(17.0 \%)\end{array}$ \\
\hline Setswana & UWN, UP, UNISA & NWU, Sol Plaaitjie, UP & $\begin{array}{l}\text { EC (63.4\%), NC } \\
(33.1 \%)\end{array}$ \\
\hline Sesotho & $\begin{array}{l}\text { UCT, UFS, SU, } \\
\text { UNISA, Wits }\end{array}$ & UFS*, CUT, UJ & FS (64.2\%) \\
\hline Tshivenda & UL, UNISA, UV & UV, UL & LP (16.7\%) \\
\hline siSwati & UNISA, UZ & $\begin{array}{l}\text { University of } \\
\text { Mpumalanga }\end{array}$ & MP (27.7\%) \\
\hline
\end{tabular}

Table 5: List of indigenous African languages with universities suggested to adopt such languages by the Ministerial Committee Report, alongside suggested universities to adopt such languages according to provincial demographics.

From Tables 4 and 5, and within the necessary considerations mentioned above, the following recommendations are made:

In Gauteng, the predominant language is isiZulu, followed by Sesotho, Sepedi and Setswana. It is recommended that UJ and TUT adopt isiZulu as it is the predominant language in the province, and because these universities are predominantly black, they cater for the largest black student populations in Gauteng. UP could adopt Sepedi or Setswana as these languages are not the predominant languages in the province nor is the black student population a majority at UP. In this regard, UPs choice in Sepedi as a third language of communication is supported. Wits could adopt Sesotho, given the university's size, black student population and that Sesotho is the second most predominant indigenous language in Gauteng. Wits' choice in adoption of Sesotho is also supported. Finally, it is recommended that VUT adopt Setswana,

111 Table 5 interpretation notes: * indicates the university should get preference for the language due to the language's predominance as a first language in the province the university is situated in. See table 4 above for further reference. 
specifically because of its smaller size and the less predominant position the language holds within Gauteng.

Setswana is the predominant language in the North West. It is therefore highly recommended that NWU adopts Setswana. In light of NWUs student demographics, it is suggested that NWU keep Afrikaans and English as mediums of instruction, as there is seemingly a demand for those languages.

For the Free State, it is recommended that UFS adopt Sesotho, coupling the predominant language in the province with the largest university therein. CUT has identified Sesotho as its language for development. It is however recommended that Sesotho may be adopted alongside isiXhosa as it is the second most wide spoken language in the province.

IsiXhosa is the predominant language spoken in the Eastern Cape. With $78.8 \%$ of first language speakers in the province, NMMU and RUs decision to adopt isiXhosa for advancement is supported. It is further recommended that, alongside NMMU and RU, UFH and WSU also adopt isiXhosa as a language for advancement. Alternatively, one of these universities may adopt Sesotho as it is the second most spoken indigenous language in the province.

IsiXhosa is also the predominant language of the Western Cape. CPUT, UCT, SU and UWC are all identified as universities which could adopt isiXhosa as a language for advancement. SU and UCTs predominantly white student population may, for the greater part, mean less willingness from students to adopt the language.

The Northern Cape only has one university, namely Sol Plaatje. In line with provincial demographics, it is suggested that the university adopts Setswana as its indigenous language for advancement. It must also be noted that Sol Plaatje, which was only founded in 2014, is a very young and small university and may, therefore, not have the necessary capacity to provide education in more than on language. In such a manner, the recommendation for NWUs adoption of Setswana would ensure that the language is advanced regardless.

The predominant language spoken in KwaZulu-Natal is isiZulu with $77.8 \%$ of the population speaking it as a first language. DUT, MUT, UKZN and UZ are all universities which could adopt isizulu for advancement.

Limpopo and Mpumalanga present the greatest challenge in national congruency in choices for adopting indigenous languages. In Limpopo (which has two universities, UV and UL) Sepedi, Tshivenda and Xitsonga are the predominant languages of the province. In Mpumalanga, with only one university, the main languages of the province are siSwati, isiZulu, Xitsonga and isiNdebele. In order to 
include all nine indigenous languages in the national framework, the following is recommended.

The University of Mpumalanga could adopt siSwati as it is the predominant language of Mpumalanga. Although isizulu is the second most prominent language in the province, universities in KwaZuluNatal as well as Gauteng would be better suited to advance isizulu. It is therefore further recommended that, where possible, Xitsonga or isiNdebele be adopted alongside siSwati.

Sepedi is the predominant language in Limpopo and as far as Limpopo is concerned, since more than half the province speaks Sepedi as a first language, notwithstanding that institutions in other provinces may choose to advance Sepedi, it should be adopted in at least one of the universities in the province. It is recommended that UL adopt Sepedi due to the large number of speakers in the province. UL is also able to accommodate a much larger number of students. UV could adopt Xitsonga or Tshivenda for advancement.

With the above recommendations in mind, it is possible that either Tshivenda, Xitsonga or isiNdebele is excluded from an institution in Limpopo or Mpumalanga. Upon such an occurrence, possible agreements could be reached between universities in neighbouring provinces, particularly those in Gauteng, in adopting any of the excluded languages for advancement in another institution. Adding to this, Unisa is yet another option in adopting such an excluded language and, furthermore, Unisa could be responsible for adopting several indigenous languages due its nature in providing distance education.

Table 6: Comparison of universities and choice of indigenous African language with recommended choice in indigenous African language

\begin{tabular}{|l|l|l|l|l|l|l|}
\hline University & Province & $\begin{array}{l}\% \text { of } \\
\text { black } \\
\text { stude } \\
\text { nts }\end{array}$ & $\begin{array}{l}\% \text { of non- } \\
\text { white } \\
\text { academic } \\
\text { staff }\end{array}$ & $\begin{array}{l}\text { Current } \\
\text { indigenous } \\
\text { language } \\
\text { identified for } \\
\text { advancement }\end{array}$ & $\begin{array}{l}\text { 1st choice } \\
\text { in } \\
\text { indigenous } \\
\text { language to } \\
\text { be adopted }\end{array}$ & $\begin{array}{l}\text { 2nd choice } \\
\text { in } \\
\text { indigenous } \\
\text { language to } \\
\text { be adopted }\end{array}$ \\
\hline UFH & EC & $95 \%$ & $72 \%$ & - & isiXhosa & - \\
\hline NMMU & EC & $59 \%$ & $27 \%$ & isiXhosa & isiXhosa & - \\
\hline RU & EC & $54 \%$ & $25 \%$ & isiXhosa & isiXhosa & - \\
\hline WSU & EC & $99.3 \%$ & $87 \%$ & - & isiXhosa & - \\
\hline CUT & FS & $46 \%$ & $46 \%$ & Sesotho & Sesotho & - \\
\hline UFS & FS & $62 \%$ & $23 \%$ & None & Sesotho & - \\
\hline UJ & GP & $87 \%$ & $43 \%$ & $\begin{array}{l}\text { Sesotho sa } \\
\text { Leboa, isiZulu }\end{array}$ & isiZulu & - \\
\hline UP & GP & $42 \%$ & $22 \%$ & Sepedi & isiZulu & - \\
\hline Unisa & GP & - & - & - & - & - \\
\hline
\end{tabular}




\begin{tabular}{|l|l|l|l|l|l|l|}
\hline TUT & GP & $93 \%$ & $56 \%$ & - & isiZulu & - \\
\hline VUT & GP & $96 \%$ & $61 \%$ & - & isiZulu & - \\
\hline Wits & GP & $58 \%$ & $38 \%$ & Sesotho & isiZulu & - \\
\hline DUT & KZN & $81 \%$ & $73 \%$ & - & isiZulu & - \\
\hline UKZN & KZN & $64 \%$ & $55 \%$ & isiZulu & isiZulu & - \\
\hline MUT & KZN & $99.6 \%$ & $90 \%$ & - & isiZulu & - \\
\hline UZ & KZN & $99.2 \%$ & $81 \%$ & - & isiZulu & - \\
\hline UL & LP & $98 \%$ & $85 \%$ & - & Sepedi & Tshivenda \\
\hline UV & LP & $99.8 \%$ & $93 \%$ & - & Xitsonga & Tshivenda \\
\hline NWU & NW & $50 \%$ & $27 \%$ & $\begin{array}{l}\text { Sesotho, } \\
\text { Setswana }\end{array}$ & Setswana & - \\
\hline CPUT & WC & $58 \%$ & $60 \%$ & - & isiXhosa & - \\
\hline UCT & WC & $33 \%$ & $29 \%$ & - & isiXhosa & - \\
\hline SU & WC & $23 \%$ & $21 \%$ & isiXhosa & isiXhosa & - \\
\hline UWC & WC & $42 \%$ & $62 \%$ & isiXhosa & isiXhosa & - \\
\hline $\begin{array}{l}\text { University of } \\
\text { Mpumalanga }\end{array}$ & MP & - & - & - & siSwati & isiNdebele \\
\hline $\begin{array}{l}\text { Sol Plaatjie } \\
\text { University }\end{array}$ & NC & - & - & - & Setswana & - \\
\hline
\end{tabular}

3.3 The Wits language policy plan: a multi-phased, holistic approach to implementation

For purposes of this article, Wits' language policy plan is discussed as one of the optimal and most practical language policy plans among higher education institutions. As Nkuna points out, implementation of university language policies, particularly in terms of incorporating indigenous languages, remains a challenge. ${ }^{112}$ Wits' choice in Sesotho is arguably a good one. A survey at the institution showed that $28.7 \%$ of respondents supported the choice in Sesotho, $11.3 \%$ of the students speak it as a first language and it is one of the predominant languages in the Iscamtho Township (within the vicinity of Wits). ${ }^{113}$ The university's strategy of focusing on only one language, developing it holistically, seems practically viable. ${ }^{114}$

The university has a detailed four phase plan for the process of incorporation and eventual use of Sesotho as a medium of instruction. ${ }^{115}$ This multi-phased approach to the development of Sesotho should be encouraged and recommended at all higher education institutions. Phase one focuses on the development of materials and resources needed for the teaching of Sesotho as a subject at all levels. During this phase, staff who wish to learn Sesotho

112 Nkuna (n 90 above) 250 - 256.

113 Foley (n 106 above) 65 - 66.

114 As above.

115 University of the Witwatersrand, Johannesburg Language Policy (n 20 above) 1 2. 
will be encouraged to do so by the university and will be provided with courses approved in terms of the skills development levy. ${ }^{116}$ Phase two will focus on the linguistic abilities of staff and students at the university. Those who do not speak an indigenous African language will be required to become communicatively competent in Sesotho. Courses for those who speak an African language will be provided to extend their competence in English. Phase three indicates that the university will play a role in the development of the Sesotho language. ${ }^{117}$ Phase four will commence once Sesotho has been developed for use as a language of instruction. In phase four, students and staff will be prepared for the introduction of English and Sesotho as mediums of instruction. ${ }^{118}$

The phased plans are also subject to time periods, with phase one being completed in 2010 and phase two having begun in 2011.

\subsection{Criticism of the policy considerations}

Although the development of indigenous languages at universities is challenging, the Ministerial Committee Report is arguably the most viably practical option. Notwithstanding this, its implementation and geographic basis does however open it up to some criticism. Its implementation faces several inherent characteristics and its criticism is briefly discussed here. The Ministerial Committee's recommendations on the language policy for higher education institutions, as Judith critically notes, has similarity to the apartheid homeland system of regional and local language use. ${ }^{119}$

The Ministerial Committee report did not totally move away from an apartheid-like use of indigenous languages based on regional and local use, and also according to the language that the tribe speaks. ${ }^{120}$ Consequently, sharing similar characteristics, this article would face the same criticism.

Another aspect which the Ministerial Committee Report also acknowledged was the conflicting nature of teaching in an indigenous language at tertiary level, while such languages are not used in primary or secondary schooling education. The Ministerial Committee acknowledged the importance of primary and secondary schooling provided in indigenous South African languages as a pivotal point in realising education in indigenous languages at higher education institutions. 121

116 As above.

117 University of the Witwatersrand, Johannesburg Language Policy (n 20 above) 2.

118 As above.

119 Judith (n 94 above) 11.

120 As above.

121 Ministerial Committee Report (n 5 above) para 48.11. 


\section{Concluding remarks}

Given the current turmoil universities are experiencing, particularly with regard to their language policies, it is clear that an action plan on the matter is needed. University language policies may embody the provisions of the 1996 Constitution, however, these language policies lack substantive and material action plans in order to advance indigenous languages and their implementation remains unrealised. University institutional language policies continue to fail at advancing the use and status of African indigenous languages. ${ }^{122}$ A national framework, one aligned with the provisions of the Language Policy for Higher Education of 2002 and the Ministerial Committee Report, is a strong and stable point of departure. If effect is to be given to section $6(2)$ and section 29(2) of the 1996 Constitution, then the advancement of indigenous languages must be made a priority at all institutions of higher education. The enhanced level of use, which English and Afrikaans currently enjoy, as well as the disregard for the development of indigenous African languages, means all official languages do not enjoy equal status in South Africa today. Each higher education institution should choose a language for advancement with national congruency in mind. Subsequent to this decision, a multiphased implementation plan should assist with both short and long term goals in the advancement of such languages.

Although this article analyses and criticises most current university language policies, the process of incorporating an indigenous language as a medium of instruction entails much more than a well thought of plan of action. University funding, availability of resources and willingness from university management structures are all massive hurdles which will need to be overcome before any indigenous African language will be utilised for teaching at higher education institutions. Given especially the enormous financial constraints government and universities are currently experiencing, the incorporation of indigenous African languages will definitely not happen in the short term, and perhaps not even in the medium to long term. ${ }^{123}$ 